\title{
Genetic diversity in several genotypes of Algerian lentil using biochemical markers
}

\author{
HAMIDA HAMMADI ${ }^{1,2, \bullet}$, DOUNIA HAMMOUDA-BOUSBIA ${ }^{1,2}$, GHANIA CHAIB ${ }^{2}$, ANFEL TIR ${ }^{3}$ \\ ${ }^{1}$ Laboratory of Biochemistry, Genetic and Vegetal Biotechnology, University of the Brothers Mentouri. Constantine 1, Route de Ain El bey, Constantine \\ 25000, Algeria \\ ${ }^{2}$ Department of Biology and Plant Ecology, Frères Mentouri University. Constantine 1, Route de Ain El Bey, Constantine 25017, Algeria. \\ Tel.: +213-557396170, "email: hammadihamida@gmail.com \\ ${ }^{3}$ Biotechnology Research Center (CRBT). BP E73, UV 03, Nouvelle Ville Ali Mendjli, Constantine, Algeria
}

Manuscript received 17 February 2021. Revision accepted: 30 May 2021

\begin{abstract}
Hammadi H, Hammouda-Bousbia D, Chaib G, Tir A. 2021. Genetic diversity in several genotypes of Algerian lentil using biochemical markers. Biodiversitas 22: 3494-2500. Studying seed storage proteins in legumes (Fabaceae) is very important besides its economic value; seed storage proteins play an important role in plant taxonomy because of the stability of their contents. The grain protein content and protein profiles of 12 lentil genotypes (Lens culinaris Medik.) were characterized based on protein profiling through SDS-PAGE. The obtained gel has shown forty bands ranged from 13 to 21 with molecular weight 10 to $120 \mathrm{KDa}$. Of which six monomorphic bands, thirty-four polymorphic bands and five unique bands in Flip90-31, Idlep3, idlep2, Idlep4 and Radjas genotypes. The protein banding pattern polymorphism $(84 \%)$ revealed an inter-genotypic variability. The Idlep3 genotype is characterized by specific bands (or a specific marker), followed by the Flip90-31 genotype. So these two genotypes can be considered as valuable gene resources for further breeding programs.
\end{abstract}

Keywords: Genotypes, Lens culinaris, protein, profiling, polymorphisms, SDS PAGE

Abbreviations: BPB: bromophenol blue; BSA: Bovine Serum Albumin; CBB: Coomassie brilliant blue; kDa: KiloDaltons; Mw: molecular weight; Rm: relative mobility; SDS-PAGE: Sodium dodecyl sulfate-polyacrylamide gel electrophoresis

\section{INTRODUCTION}

Lentil (Lens culinaris Medik.) is one of the ancient legumes to be cultivated in the world (Abraham 2015), the trace of the L. culinaris in Greece dates from 11,000 BC, and in Syria dates from 8,500. His center of origin is located in the Near East, and the cultivation of the species has started in this region BC (Ladizinsky 1979). It is selfpollinating, diploid $(2 n=2 \times=14$ chromosomes). Lentil seeds are rich in high levels of antioxidants, proteins, vitamins, minerals and dietary fiber for nutrition (Karimizadeh et al. 2012) and play an important role in crop rotations because of their nitrogen-fixing capability. Lentil in Algeria has great importance in living and is included in the daily diet, and therefore it is the focus of several different studies in cytogenetic, genetic, and morphological fields (Hammouda and Khalfllah 2015; Hammadi et al. 2018; Gaad et al. 2018). However, there are no studies on seed storage protein profile using SDS-PAGE technique on lentils in Algeria.

The seeds of plants are not only organs of propagation and dispersal but also the major plant tissue harvested by humans. There are significant amounts of protein in the seeds and vary from one type to another, for example, $10 \%$ (in grains) $40 \%$ (in legumes) of the dry weight, which constitutes a major source of dietary protein (Arslan 2012). Storage proteins are vital because they determine not only the total protein content of seeds but also their quality for different uses (Arslan 2012).

Multiple markers, including biological and morphological markers that are used for long, can mainly detect genetic diversity time (Abdul-Razzak and Omer 2017). However, these markers are affected by environmental conditions and have some limitations. Sodium Dodecyl Sulphate-Polyacrylamide Gel Electrophoresis (SDS-PAGE) of storage seed proteins is the most commonly used method to discriminate the varieties, and it is used for selection and genetic diversity analysis (Arslan 2012) of lentil and other crops. It has been applied to several organisms: bacteria, animals, and plants because $t$ is relatively simple and easy to achieve. The present investigation involves: (i) Determination of protein content of the lentil genotypes; (ii) Determination of the profile of seed storage proteins in certain genotypes; (iii) Cluster analysis for the assessment of differences between genotypes; (iv) The highlighting the intra-specific and inter-genotypic polymorphism(s); (v) Assessment of genetic distances.

The genetic relationship was discovered in this study may form the basis for future systematic lentil breeding programs, The aim of the present study was to find out genetic diversity of 12 different genotypes of lentils using protein profiling by SDS-PAGE. 


\section{MATERIALS AND METHODS}

The study was conducted at National Research Center of Biotechnology, Constantine, Algeria (CRBt). The plant material consists of twelve genotypes (Figure 1, Table 1) of Lens culinaris $(2 \mathrm{n}=2 \mathrm{x}=14)$, from different regions in Algeria.

\section{Protein extraction}

The grains of lentil were ground to fine powder and 10 $\mathrm{mg}$ was weighed in $1.5 \mathrm{ml}$ microtube, $400 \mu \mathrm{l}$ protein extraction buffer (Tris-Hcl 0.05M (pH 8), 0.02\% SDS, $30.3 \%$ urea, $1 \%$ 2-mercaptoethanol) was added to each micro-tube, kept overnight at $40^{\circ} \mathrm{C}$ and centrifuged at $13000 \mathrm{rpm}$ for $10 \mathrm{~min}$. The supernatant contain dissolved extracted protein ready for experiment purposes, which could be kept for longer time at $4^{\circ} \mathrm{C}$.

\section{Protein estimation}

Protein estimation of extracts was measured immediately and directly from the supernatant by dyebinding assay as described by (Bradford 1976).

\section{Electrophoresis}

Before starting the electrophoresis process, $50 \mu \mathrm{L}$ supernatant was mixed with $10 \mu \mathrm{L}$ sample buffer and heated in a $1.5 \mathrm{ml}$ Eppendorf tube in the water bath at $95^{\circ} \mathrm{C}$ for $5 \mathrm{~min}$ to denature the protein. After that, the protein samples were subjected to one dimensional (SDS-PAGE) in a gel slab of $1 \mathrm{~mm}$ thickness $(5 \%$ stacking gel $=2.5 \mathrm{~cm}$ height and $15 \%$ separating gel $=5.5 \mathrm{~cm}$ height )as described by Laemmli (1970). Electrophoresis was performed with a discontinuous buffer system in a vertical electrophoresis unit. The gel was run until the bromophenol blue marker had reached the bottom of the gel. The gel was stained in a staining solution (10\%Ethanol; $6.6 \%$ acetic acid $0.05 \%$ Coomassie Brilliant Blue G-250) overnight. The gel was destained in the de-staining solution (40\% ethanol; $7 \%$ acetic acid) overnight until the color of background disappeared. Finally, gels were photographed and scanned using Bio-Rad software. Detailed analysis of protein and patterns in terms of band number, mobility of protein bands, staining intensity, band percentage, and the determination of molecular weight of each band.

Table 1. Genotypes lists and their origins of Lens culinaris

\begin{tabular}{llccc}
\hline Under species & \multicolumn{1}{c}{ Genotypes } & Generation & Origins & Source \\
\hline Microsperma & Syrie229 & F6 & ICARDA(Syria) & ITGC El Khroube \\
& Dahra & F6 & Local selection (Tieret, Algeria) & ITGC Setif \\
& Idlep1 & F5 & ICARDA(Syria) & ITGC Mila \\
& Idlep2 & F6 & ICARDA(Syria) & ITGC Setif \\
& Idlep3 & F6 & ICARDA(Syria) & ITGC El Khroube \\
& & & & CNCC El Khroube \\
& Ibla Flip90-31 & F6 & ICARDA(Syria) & ITGC El Khroube \\
& Balkane775 & F6 & ICARDA(Syria) & CNCC El Khroube \\
& Metropole & F5 & Isolated in 1941, France & ITGC Mila \\
\hline
\end{tabular}

Note: ICARDA: International Center for Agricultural Research in the Dry Areas, Aleppo, Syria; ITGC: Technical Institute of Field, Constantine, Algeria; CNCC: National Center of Control and Certification of seeds and plants, Constantine, Algeria.
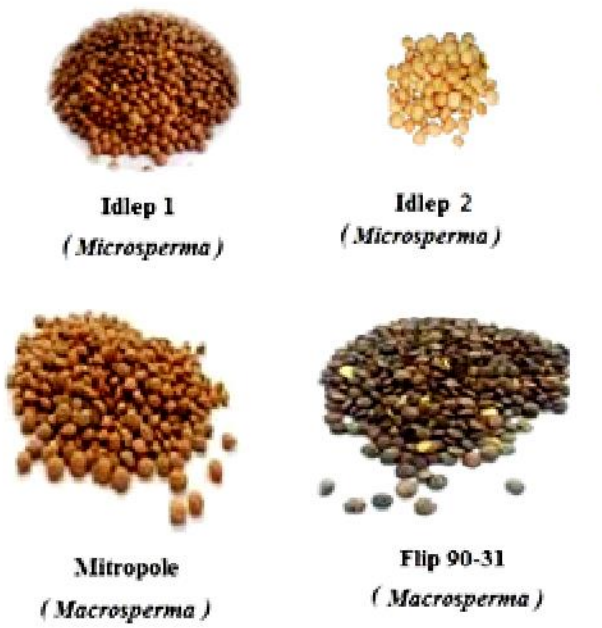

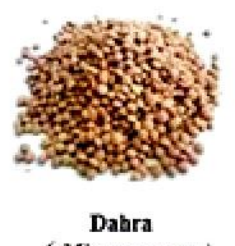

( Microsperma)
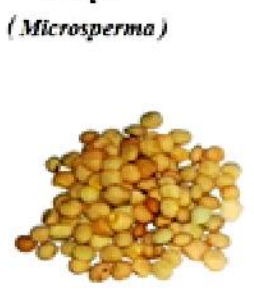

Balkan 755

( Macrosperma)

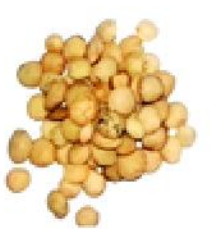

Nil 45

(.Macrosperma)
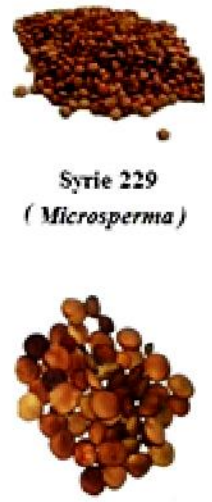

Radjas

( Macrosperma)

Figure 1. The seeds of 12 lentils (Lens culinaris) genotypes used in this study 


\section{Data analysis}

The gels were photographed and scanned using BioRad, a USA-made Gel-DocTM XR+ system. The bands were visually scored as present (1) or absent (0) for seed storage protein gel. Only the lightest and strongest bands were recorded and used for analysis. These bands were entered into a binary data matrix. Statistical analyzes were performed with XLSTAT 2014 software.

\section{RESULTS AND DISCUSSION}

The results obtained by the SDS-PAGE technique of 12 lentil genotypes were distinguished by the presence and absence of protein bands at a particular molecular weight. They revealed intergenotypic qualitative and quantitative differences in the total number of protein bands, position, thickness, and intensity staining (Figures 2, 3, and 4).

The results showed common bands between genotypes, and specific bands (markers) were particular in the Idlep3 genotype. In addition, there is a difference in the thickness of the bands. In each genotype, the number of bands varied from 15 to 21 with molecular weight between 10 to 120 kDa (Table 2) (Figure 4).

Minimum bands (13 in number) were observed in the Radjas genotype, 15 bands in the Dahra genotype, 16 bands in the Idlep1, Ibla, Metropole, Balkane, Nile 45, and Syrie 229 genotypes, 17 bands in the genotype Idlep2 and Idlep4,
18 bands in the Flip90-31 genotype. The maximum bands (21 in number) were marked in the Idlep3 genotype (Table 2) (Figure 4).

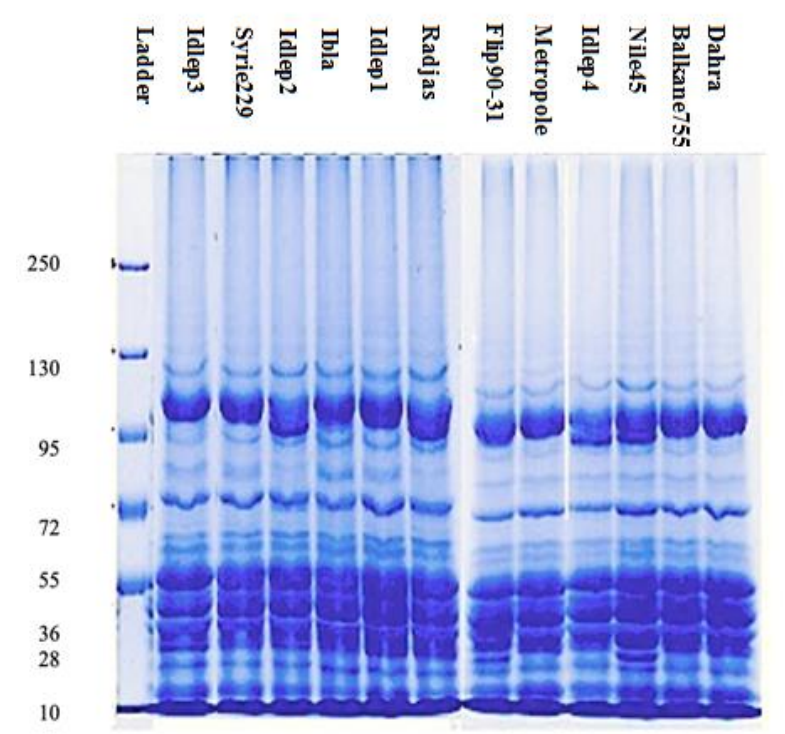

Figure 2. Electropherogram of 12 lentil genotypes showing protein banding pattern through SDS-PAGE
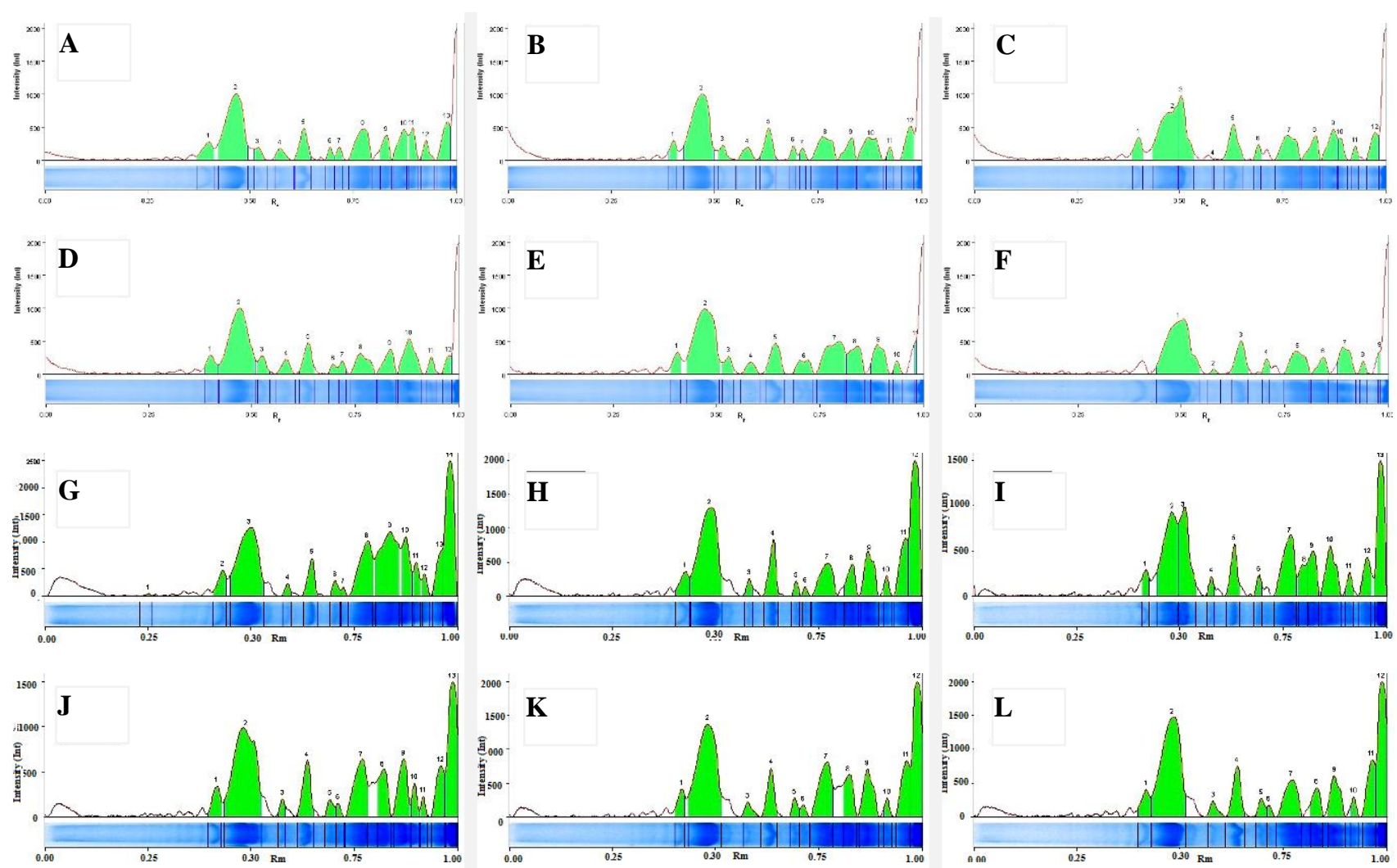

Figure 3. The number of peaks of different heights obtained based on the intensity of bands against their respective relative mobility (Rm value) of bands (A: Idlep3, B: Syrie229, C: Idlep2, D: Ibla, E: Idlep1, F: Radjas, G: Flip90-3, H: Metropole, I: Idlep4, J: Nile45, K: Balkane755, L: Dahra. 
Table 2. Molecular weight (presence of bands (+), absence of bands (-) ) of seed storage protein in12 lentil genotype using SDS-PAGE (M: monomorphic bands, P: polymorphic bands, U: unique bands)

\begin{tabular}{|c|c|c|c|c|c|c|c|c|c|c|c|c|c|c|}
\hline $\begin{array}{c}\text { Band } \\
\text { no. }\end{array}$ & $\begin{array}{l}\text { Mw } \\
\text { kDa }\end{array}$ & Idlep3 & $\begin{array}{c}\text { Syrie22 } \\
9\end{array}$ & Idlep2 & Ibla & Idlep1 & Radjas & $\begin{array}{c}\text { Flip90- } \\
31\end{array}$ & $\begin{array}{c}\text { Metro- } \\
\text { pole }\end{array}$ & Idlep4 & Nile45 & $\begin{array}{c}\text { Balkan } \\
\text { e755 }\end{array}$ & Dahra & $\begin{array}{l}\text { Band } \\
\text { type }\end{array}$ \\
\hline 1 & 120 & 1 & 1 & 1 & 1 & 1 & 1 & 1 & 1 & 1 & 1 & 1 & 1 & $\mathrm{M}$ \\
\hline 2 & 114.9 & 0 & 0 & 0 & 0 & 0 & 0 & 0 & 0 & 1 & 1 & 1 & 1 & $\mathrm{P}$ \\
\hline 3 & 112.1 & 1 & 1 & 1 & 1 & 0 & 0 & 1 & 1 & 0 & 0 & 0 & 0 & $\mathrm{P}$ \\
\hline 4 & 111 & 1 & 1 & 1 & 1 & 1 & 1 & 1 & 1 & 1 & 1 & 1 & 1 & M \\
\hline 5 & 99.5 & 0 & 0 & 0 & 0 & 0 & 0 & 0 & 0 & 1 & 0 & 1 & 1 & $\mathrm{P}$ \\
\hline 6 & 98.2 & 1 & 1 & 0 & 1 & 0 & 0 & 0 & 1 & 0 & 1 & 0 & 0 & $\mathrm{P}$ \\
\hline 7 & 96.6 & 0 & 0 & 0 & 0 & 1 & 0 & 1 & 0 & 0 & 0 & 0 & 0 & $\mathrm{P}$ \\
\hline 8 & 94.8 & 0 & 0 & 1 & 0 & 0 & 0 & 0 & 0 & 1 & 0 & 0 & 0 & $\mathrm{P}$ \\
\hline 9 & 92.6 & 0 & 0 & 0 & 0 & 0 & 1 & 0 & 0 & 0 & 0 & 0 & 0 & $\mathrm{u}(+)$ \\
\hline 10 & 91.0 & 0 & 0 & 1 & 0 & 0 & 0 & 0 & 0 & 0 & 0 & 0 & 0 & $\mathrm{u}(+)$ \\
\hline 11 & 88.7 & 1 & 1 & 0 & 0 & 0 & 0 & 0 & 0 & 0 & 0 & 0 & 0 & $\mathrm{P}$ \\
\hline 12 & 87.5 & 0 & 0 & 0 & 1 & 1 & 0 & 0 & 0 & 0 & 0 & 0 & 0 & P \\
\hline 13 & 81.0 & 0 & 0 & 0 & 0 & 0 & 0 & 0 & 0 & 1 & 1 & 1 & 0 & $\mathrm{P}$ \\
\hline 14 & 79,8 & 1 & 1 & 1 & 1 & 1 & 1 & 1 & 1 & 0 & 0 & 0 & 1 & $\mathrm{p}$ \\
\hline 15 & 72 & 0 & 0 & 0 & 0 & 0 & 0 & 0 & 0 & 1 & 1 & 1 & 0 & $\mathrm{P}$ \\
\hline 16 & 71.4 & 1 & 1 & 1 & 0 & 0 & 0 & 0 & 1 & 0 & 0 & 0 & 1 & $P$ \\
\hline 17 & 70.2 & 0 & 0 & 0 & 1 & 1 & 1 & 1 & 0 & 0 & 0 & 0 & 0 & $\mathrm{P}$ \\
\hline 18 & 64.4 & 1 & 0 & 0 & 0 & 0 & 0 & 0 & 0 & 1 & 1 & 1 & 0 & $\mathrm{P}$ \\
\hline 19 & 63.8 & 0 & 1 & 1 & 0 & 0 & 0 & 0 & 1 & 0 & 0 & 0 & 1 & $\mathrm{P}$ \\
\hline 20 & 62.8 & 1 & 0 & 0 & 1 & 0 & 1 & 1 & 0 & 0 & 1 & 1 & 0 & $\mathrm{P}$ \\
\hline 21 & 61.2 & 0 & 0 & 0 & 0 & 1 & 0 & 0 & 1 & 0 & 0 & 1 & 1 & $\mathrm{P}$ \\
\hline 22 & 60.7 & 1 & 0 & 0 & 1 & 1 & 0 & 1 & 0 & 0 & 0 & 0 & 0 & $\mathrm{P}$ \\
\hline 23 & 55.0 & 1 & 1 & 1 & 1 & 1 & 1 & 1 & 1 & 1 & 1 & 1 & 1 & M \\
\hline 24 & 51.8 & 1 & 0 & 0 & 0 & 0 & 0 & 0 & 0 & 0 & 0 & 0 & 0 & $\mathrm{u}(+)$ \\
\hline 25 & 50.0 & 0 & 0 & 0 & 0 & 0 & 0 & 1 & 0 & 0 & 0 & 0 & 0 & $\mathrm{u}(+)$ \\
\hline 26 & 47.9 & 0 & 0 & 0 & 0 & 1 & 1 & 0 & 0 & 0 & 0 & 0 & 0 & $\mathrm{P}$ \\
\hline 27 & 40.5 & 0 & 0 & 0 & 0 & 0 & 0 & 0 & 0 & 1 & 0 & 0 & 0 & $\mathrm{P}$ \\
\hline 28 & 34.2 & 0 & 0 & 0 & 0 & 0 & 0 & 0 & 0 & 1 & 1 & 1 & 0 & $\mathrm{P}$ \\
\hline 29 & 30.7 & 1 & 1 & 1 & 0 & 0 & 0 & 0 & 1 & 0 & 0 & 0 & 1 & $\mathrm{P}$ \\
\hline 30 & 29.8 & 0 & 0 & 0 & 1 & 1 & 0 & 1 & 0 & 0 & 0 & 0 & 0 & $\mathrm{P}$ \\
\hline 31 & 28 & 1 & 1 & 1 & 1 & 1 & 1 & 1 & 1 & 1 & 1 & 1 & 1 & $\mathrm{M}$ \\
\hline 32 & 19.4 & 0 & 0 & 0 & 0 & 0 & 0 & 0 & 0 & 1 & 0 & 0 & 0 & $\mathrm{u}(+)$ \\
\hline 33 & 17 & 1 & 1 & 1 & 0 & 0 & 0 & 0 & 0 & 1 & 1 & 1 & 1 & $\mathrm{P}$ \\
\hline 34 & 16.8 & 1 & 0 & 1 & 0 & 0 & 0 & 1 & 1 & 0 & 0 & 0 & 1 & $\mathrm{P}$ \\
\hline 35 & 15 & 1 & 1 & 1 & 1 & 1 & 1 & 1 & 0 & 0 & 1 & 0 & 0 & $\mathrm{P}$ \\
\hline 36 & 14 & 1 & 1 & 1 & 1 & 1 & 1 & 0 & 1 & 1 & 1 & 1 & 0 & $\mathrm{P}$ \\
\hline 37 & 13.5 & 0 & 0 & 0 & 0 & 0 & 0 & 1 & 0 & 0 & 0 & 0 & 1 & $\mathrm{P}$ \\
\hline 38 & 11.5 & 1 & 1 & 1 & 1 & 1 & 1 & 1 & 1 & 1 & 1 & 1 & 1 & M \\
\hline 39 & 10.3 & 1 & 0 & 0 & 0 & 0 & 0 & 1 & 1 & 0 & 0 & 0 & 0 & $\mathrm{P}$ \\
\hline \multirow[t]{2}{*}{40} & 10 & 1 & 1 & 1 & 1 & 1 & 1 & 1 & 1 & 1 & 1 & 1 & 1 & M \\
\hline & Total & 21 & 16 & 17 & 16 & 16 & 13 & 18 & 16 & 17 & 16 & 16 & 15 & \\
\hline
\end{tabular}

To determine the intervarietal correlation between cultivars, only clearly recognizable protein bands were visually marked. In our case, the total number of bands identified is forty, including thirty-four polymorphic bands (five unique bands (specific marker) and twenty nine nonunique bands), six monomorphic bands, indicating the presence of significant polymorphism with $85 \%$ (Figure 5). The gel was divided into six regions with molecular marker intervals between 10 to $120 \mathrm{kDa}$ based on the banding pattern.

The study of protein content is related to the study of SDS-PAGE to determine the quality of the protein, the quantitative variation of seed proteins between different lentil genotypes is studied and represented by a bar chart in Figure 6. The high protein content, $19.81 \%$, was obtained in Flip90 - 31 and $19.13 \%$ in Idlep3. However, in other genotypes such as Idlep1, Metropole, Ibla, Dahra,
Balkane755, Syrie229, Idlep4, Radjas, Nil45 and Idlep2, the protein content of seeds was $18.46 \%, 17.85 \%, 17.63 \%$, $17.15 \%, 17.00 \%, 16.59 \%, 16.36 \%, 16.35 \%, 16.13$ and $15.10 \%$ respectively.

The similarity matrices, estimated from simple correspondence coefficients, were used to construct a dendrogram using the UPGMA method with forty SDSPAGE bands (Figure 7). Genetic similarity coefficients varied among lentil genotypes (Table 3). The highest similarity coefficient (0.792) was observed between Nile45 and Balkane 755 genotypes.

The second highest similarity coefficient (0.743) was observed between Balkane755 and Idlep4 genotypes. However, the lowest similarity coefficient was noticed between the genotypes Balkane755 and Flip90-31(-0.021). The dendrogram (Figure 7) clearly showed two distinct clusters at the similarity coefficient level of -0.021 . 
The major and large cluster was divided into two clusters. The one cluster is divided into two sub-cluster: the one sub-cluster consisted of Ibla, Idlepland Radjas genotypes (Ibla, Idlep1 together $(0.68 \%)$, and Radjas are alone $(0.63 \%$ between Radjas and Idlep1), and Flip90-31 were positioned alone as sub-cluster ( $0.44 \%$ between Flip90-31 and Radjas). This genotype is different from the others.

The one cluster is subdivided into two sub-clusters: the one sub-cluster consisted of Syrie229, Idlep2 (0.74\%),

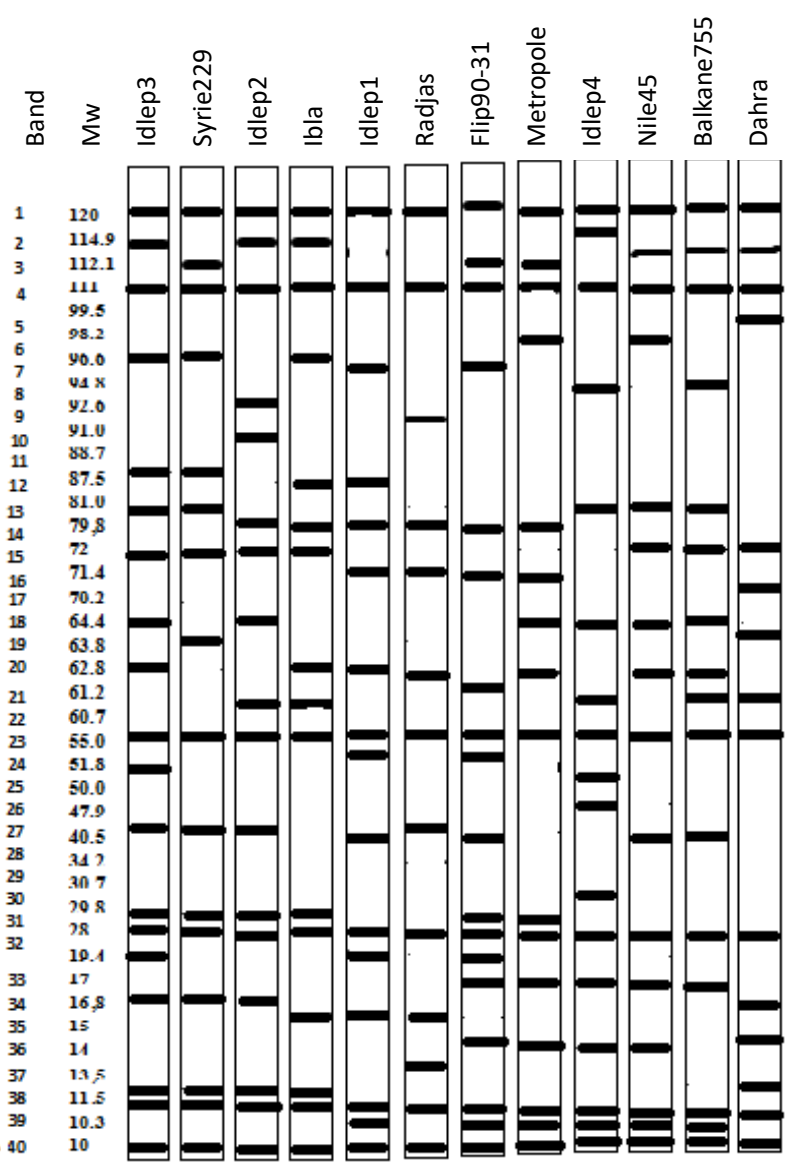

Figure 4. Zymogram of SDS-PAGE of 12 lentil genotypes

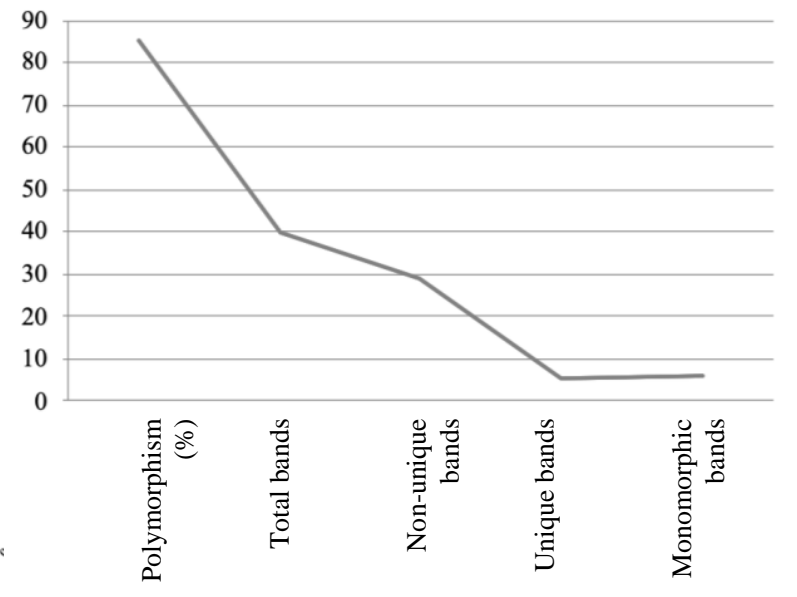

Figure 5. Polymorphism, total bands, polymorphic bands, unique bands, and monomorphic bands of seed with protein profiles in 12 lentil genotypes which are genetically close to each other, and Metropole $(0.64 \%)$, and Idlep3 $(0.57 \%)$ was positioned alone as a subcluster. The second sub-cluster consisted of Dahra $(0.26 \%)$ were positioned alone as sub-cluster, so, genetically, they are far from other genotypes. The second main cluster consisted of Nile45, Balkane (0.79\%), and Idlep 4 (0.74\%). In this cluster, Idlep4 has positioned itself alone as a subcluster. This genotype is different from the others.

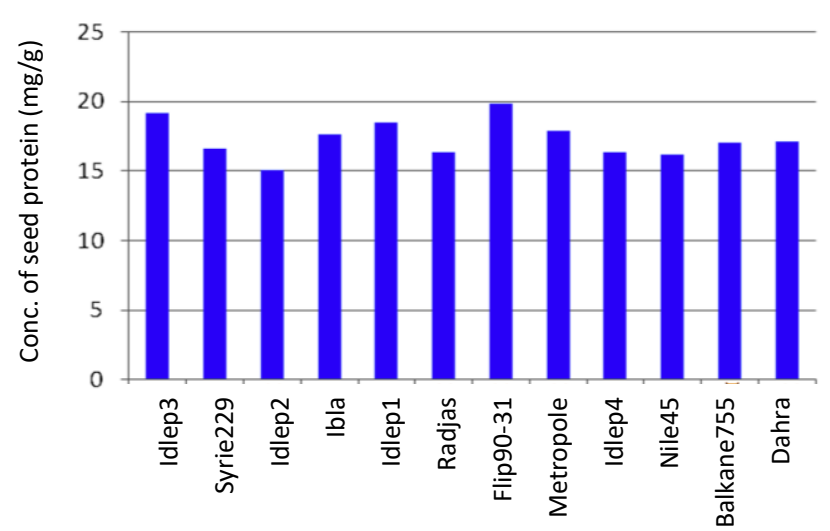

Figure 6. Protein content $\%$ of 12 lentil genotypes

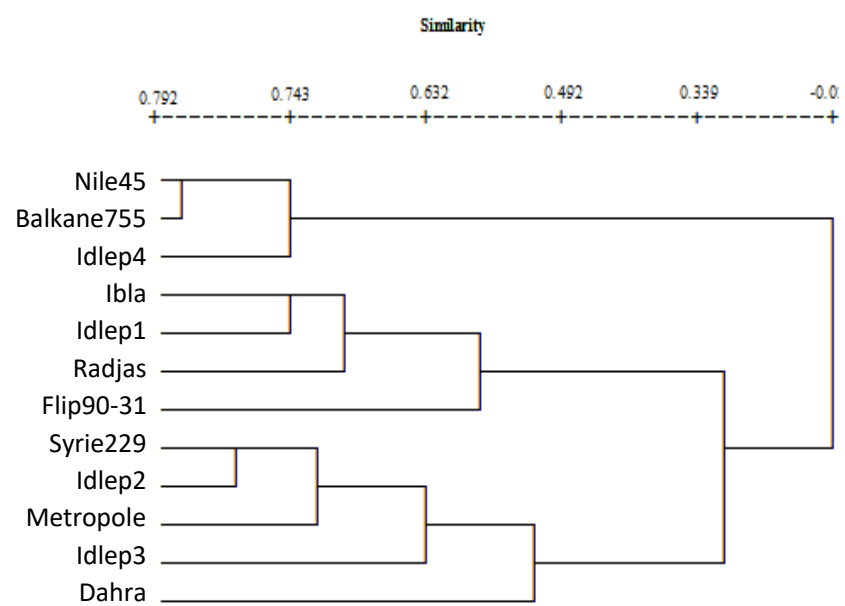

Figure 7. SDS-PAGE dendrogram of 12 genotypes of lentil seed based on protein banding pattern using UPGMA cluster analysis

\section{Discussion}

Lentil is an important food legume known for its quality. Therefore, improving new lentil cultivars is essential for sustainable production. We need the revelation of genetic variation among lentil genotypes to breed a new variety with the desired agronomic and commercial characters (Kumar et al. 2018).

Seed storage protein markers, a type of biochemical marker, can be used for selection and genetic diversity analysis (Arslan 2012) of lentil and other crops.SDS-PAGE of storage seed proteins is the most commonly used method to discriminate the varieties. Band patterns indicate differences between varieties in the number of bands, band position, and molecular weight of bands (Hoque and Hasan 2012). 
Table 3. Similarity matrices in 12 lentil genotype based on seed storage proteins

\begin{tabular}{|c|c|c|c|c|c|c|c|c|c|c|c|c|}
\hline Genotypes & Idlep3 & Syrie229 & Idlep2 & Ibla & Idlep1 & Radjas & Flip90-31 & Metropole & Idlep4 & Nile45 & Balkane755 & Dahra \\
\hline Idlep3 & 1 & & & & & & & & & & & \\
\hline Syrie229 & 0.674 & 1 & & & & & & & & & & \\
\hline Idlep2 & 0.514 & 0.743 & 1 & & & & & & & & & \\
\hline Ibla & 0.470 & 0.479 & 0.330 & 1 & & & & & & & & \\
\hline Idlep1 & 0.164 & 0.271 & 0.227 & 0.688 & 1 & & & & & & & \\
\hline Radjas & 0.339 & 0.414 & 0.375 & 0.632 & 0.632 & 1 & & & & & & \\
\hline Flip90-31 & 0.357 & 0.185 & 0.239 & 0.595 & 0.492 & 0.445 & 1 & & & & & \\
\hline Metropole & 0.572 & 0.688 & 0.640 & 0.375 & 0.271 & 0.305 & 0.287 & 1 & & & & \\
\hline Idlep4 & 0.008 & 0.124 & 0.182 & 0.021 & 0.021 & 0.159 & -0.168 & 0.021 & 1 & & & \\
\hline Nile45 & 0.368 & 0.375 & 0.227 & 0.375 & 0.167 & 0.414 & 0.082 & 0.167 & 0.640 & 1 & & \\
\hline Balkane755 & 0.164 & 0.167 & 0.124 & 0.167 & 0.167 & 0.305 & -0.021 & 0.167 & 0.743 & 0.792 & 1 & \\
\hline Dahra & 0.266 & 0.479 & 0.537 & 0.063 & 0.167 & 0.196 & 0.185 & 0.583 & 0.227 & 0.167 & 0.375 & 1 \\
\hline
\end{tabular}

This study found that seed storage protein in lentils is may reveal usable protein band polymorphism to study the diversity of the genotypes and the information could help make decisions regarding the choice for selecting parents for improvement of lentil productivity through hybridization. Forty polypeptide bands were detected, and molecular weight ranged from 10 to $120 \mathrm{kDa}$.

Kumar et al. (2018) reported that band patterns obtained from the 14 lentil cultivars and 23 polypeptide bands were detected and from Sultana and Ghafoor (2008). They recorded 55 protein bands in lentils ranging from the molecular mass of 14 to $66 \mathrm{kDa}$, and 13 of these were polymorphic, and Erdogan (2015) reported that band patterns were obtained from the 13 lentil cultivars, and a total of 22 polypeptide bands were detected. Therefore, our results are similar to those of the authors (Kumar et al. 2018).

The characterization of genotypes based on protein/seed storage subunits is well documented in different crops, including legumes (Hamdi et al. 2012), Vigna spp. (Rao et al.1992), Vigna unguiculata (Sharma 2012, Koolwal 2015), fenugreek (Pareek 2014), and mustard (Parashar et al. 2015).

Seed proteins were successfully used to study the variation of storage proteins in lentils. According to Madina et al. (2013), the region I was for albumin protein, more than $60 \mathrm{kDa}$ of ovalbumin protein, $45 \mathrm{kDa}$ to $66 \mathrm{kDa}$ of carbonic anhydrase protein, $29 \mathrm{kDa}$ to $45 \mathrm{kDa}$ trypsin inhibitor $20.1 \mathrm{kDa}$ to $29 \mathrm{kDa}$, lysozyme 14.4 to $20.1 \mathrm{kDa}$, aprotinin $10 \mathrm{kDa}$ to $14.4 \mathrm{kDa}$. From six types of seed storage proteins, the albumin protein was abundant in all varieties. In general, legumes contain mainly albumins (20$35 \%$ ) and globulins (43-55\%) (Tchiagam et al. 2011).

In all genotypes, the protein content of the seed varied from $15.10 \%$ to $19.81 \%$. However, it appears that clusters did not affect a particular trend in protein content, as all clusters included genotypes with lower or higher protein content of the seeds. This result is consistent with that of (Tuhin et al. 2016).

The dendrogram was building by the UPGMA method with forty SDS-PAGE bands, It was revealed that at similarity coefficient level of -0.021 two major clusters are separated. Indeed, it was indicated higher variability dissimilarity estimates among lentil genotypes, and this is similar to what he found (El Nahas et al.2011) also studied the analysis of seed proteins of 6 genotypes by SDS PAGE, which showed that each genotype was distinct from other. According to Madina et al.( 2013), the protein banding pattern obtained showed a polymorphism of $57.12 \%$ and could be considered as a general biochemical fingerprint of the lens. Other authors (Tuhin et al. 2016) showed a slight polymorphism (14.285\%), indicating a low genetic diversity of the five varieties, and (Wadood et al. 2016) showed that SDS-PAGE displayed a low-level genetic polymorphism in 60 cultivars of lentil but higher than in other legumes, and it can be increased by the addition of more extensively sourced germplasm. In contrast, in our case, binary data obtained by protein gel electrophoresis in 12 lentil genotypes showed a polymorphism of $85 \%$. It means that the level of protein polymorphism is high and is correlated with high genetic diversity. These results are similar to what he found (Jukanti et al. 2017), who studied six arid grain legumes where he found an intra-varietal and inter-specific variability in grain protein content.

In a conclusion, the study of the seed storage profile of protein markers of twelve lentil genotypes using (SDSPAGE), showed about forty polypeptide bands, whose molecular weight varied from 10 to $120 \mathrm{kDa}$, indicating the presence of significant polymorphism with $85 \%$ between these genotypes, which explains the presence of intergenotypic diversity. The Idlep3 and Flip90-31 genotypes are characterized by specific bands, so both genotypes can be considered as valuable genetic resources for Algerian lentil selection programs.

\section{ACKNOWLEDGEMENTS}

The author would like to thank the director of the Biotechnology Research Center (CRBT), Constantine, Algeria, for helping us complete this work. 


\section{REFERENCES}

Abdul-Razzak N T, Omer DA. 2017. Genetic variation in lentil genotypes by morpho-agronomic traits and RAPD-PCR. J Anim Plant Sci 27 (2): 468-480.

Abraham R. 2015. Lentil (Lens culinaris Medik) current status and future prospect of production in Ethiopia. Adv Plants Agric Res 2 (2): $45-$ 53.

Arslan M. 2012. Evaluation of genetic similarity and agronomic traits of castor bean populations naturally grown in the Eastern Mediterranean region of Turkey. Biotechnol Biotechnol Equip 26: 3089-3093. DOI: 10.5504/BBEQ.2012.0034

Bradford MM. 1976. A rapid and sensitive method for the quantitation of microgram quantities of protein utilizing the principle of protein-dye binding. Ann Biochem 72: 248-254. DOI: 10.1016/00032697(76)90527-3.

Gaad DJ, Meriem L, Fatima G, Abdelgurfi A. 2018. Collection and agro morphological characterization of Algerian accessions of lentils (Len culinaris). Biodiversitas 19 (1): 183-193. DOI 10.13057/biodiv/d190125.

El Nahas AI, El Shazly HH, Ahmed SM, Omran AAA. 2011. Molecular and biochemical markers in some lentil genotypes. Ann Agric Sci 56: 105-112. DOI: 10.1016/j.aoas.2011.11.001.

Erdogan C. 2015. Genetic characterization and cotyledon color in lentil Chilean J Agric Res 75 (4): 383-389. DOI: 10.4067/S071858392015000500001.

Hamdi A, Ali MA, Shaaban M, Ezzat MZ. 2012. Agronomic, seed protein and quality characters of the most promising lentil genotypes in Egypt. World Appl Sci J 20 (1): 70-79.

Hammadi H, Hammouda D, Djeghar R. 2018. Distribution of heterochromatic variability in several genotypes of Lens culinaris Medik (SSP microsperma and macrosperma). Intl J Sci Res 7: 1112.

Hammouda D, Khlafllah N. 2015. Etude comparative de la caryomorphologie chez six génotypes du Lens culinaris Medik. Eur Sci J 11: 212-214.

Hoque ME, Hasan MM. 2012. Molecular diversity analysis of lentil (Lens culinaris Medik.) through RAPD markers. Plant Tiss Cult Biotechnol 22: 51-58. DOI: $10.3329 /$ ptcb.v22i1.11260.

Jukanti AK, Dagla HR, Kalwani1 P, Goswami D, Upendra JM, Kalia RK, Bhatt RK. 2017. Grain protein estimation and SDS-PAGE profiling of six important arid legumes. Legume Res 40: 485-490. DOI: 10.18805/lr.v0i0.7295

Karimizadeh R, Muhammadi M, Shefazadeh MK, Mahmoodi AA, Rustami B, Karimpur F. 2012. Relationship among and repeatability of ten stability indices for grain yield of food lentil genotypes in Iran. Turkish J Field Crops 17: 51-61.
Kumar P, Ankita T, Anupam A, Rahul V, Rajesh K, Vyas RP, Yadav MK. 2018. Genetic characterization of lentil genotypes based on SDSPAGE. J Pharmacog Phytochem 7: 274-278.

Koolwal A. 2015. Genetic diversity in cowpea (Vigna unguiculata (L.) Walp.) Genotypes for Storage Seed Protein Profile. [Thesis]. S.K.R.A.U. Bikaner, Campus-Jobner.

Ladizinsky G, Hymowitz T. 1979. Seed protein electrophoresis in taxonomic and evolutionary studies. Theor Appl Genet 54: 145-151. DOI: $10.1007 / \mathrm{BF} 00263044$

Laemmli UK. 1970. Cleavage of structural proteins during the assembly of the head of bacteriophage T4. Nature 227 (5259): 680-685. DOI: 10.1038/227680a0.

Madina MH, Haque ME, Dutta AK, Islam MA, Deb AC, Sikdar B. 2013. Estimation of genetic diversity in six lentils (Lens culinaris Medik.) varieties using morphological and biochemical markers. Intl J Sci Eng Res 4 (9): 819-823.

Parashar N, Jakhar ML, Ram Krishna K, Jangid K. 2015. Genetic diversity for storage seed protein profile in mustard (Brassica juncea (L.) Czern. \& Coss.) genotypes. Ecoscan 8: 177-182.

Pareek A. 2014. Genetic diversity for storage seed protein profile in fenugreek (Trigonella foenumgreacum L.) genotypes. [Thesis]. S.K.R.A.U. Bikaner, Campus-Jobner.

Rao R, Vagliol MD, D'Urzo MP, Month L. 1992. Identification of Vigna spp. through specific seed storage polypeptides. Euphytica 62: 39-43. DOI: $10.1007 / \mathrm{BF} 00036085$

Sharma BD. 2012. Genetic diversity in cowpea (Vigna unguiculata (L.) Walp.) using protein profile. [Thesis]. S.K.R.A.U. Bikaner, CampusJobner.

Sultana T, Ghafoor A. 2008. Genetic diversity in ex-situ conserved Lens culinaris for botanical descriptors, biochemical and molecular markers, and identification of landraces from indigenous. Genet Resour Pak J Integr Plant Biol 50: 484-490.

Wadood SF, Hassan N, Khaliq A, Nausheen, Jan T, Ghafoor A, Khan M, Nisar M. 2016. Genetic polymorphism in Lens culinaris collected from Malakand division Khayber Pakhtunkhwa. Pak J Biodiver Environ Sci 8: 53-60.

Tchiagam JBN, Bell JM, Nassourou AM, Njintang NY, Youmbi E. 2011. Genetic analysis of seed protein contents in cowpea (Vigna unguiculata L. Walp.). Afr J Biotechnol 10: 3077-3086. DOI: 10.5897/AJB10.2469.

Tuhin P, Ghosh S, Mondal A, De KK. 2016. Evaluation of genetic diversity in some promising varieties of lentil using karyological characters and protein profiling, J Genet Eng Biotechnol 14 (1): 3948. DOI: 10.1016/j.jgeb.2016.03.003. 